\title{
Low levels of genetic diversity depicted from mitochondrial DNA sequences in a heavily exploited marine fish (Cynoscion acoupa, Sciaenidae) from the Northern coast of Brazil
}

\author{
Rosa Rodrigues ${ }^{1}$, Horacio Schneider ${ }^{1}$, Simôni Santos ${ }^{1}$, Marcelo Vallinoto ${ }^{1}$, Ulrich Sain-Paul ${ }^{2}$ \\ and Iracilda Sampaio ${ }^{1}$ \\ ${ }^{1}$ Laboratório de Genética e Biologia Molecular, Instituto de Estudos Costeiros, \\ Universidade Federal do Pará, Campus de Bragança, Aldeia Bragança, PA, Brazil. \\ ${ }^{2}$ Center for Marine and Tropical Ecology, Fahrenheitstr, Bremen, Germany.
}

\begin{abstract}
The acoupa weakfish (Cynoscion acoupa - Sciaenidae) is a marine species of croaker with estuarine-dependent behavior, found in the western Atlantic from Panama to Argentina. It is one of the most exploited food fish on the northern coast of Brazil. In this study, DNA sequences were determined from the entire control region (D-loop) of the mitochondrial genome of 297 individuals collected during seven different months between December 2003 and August 2005 on the northern coast of Brazil (Amapá and Pará). Genetic variability expressed by haplotype $(h=0,892)$ and nucleotide $(\pi=0,003)$ diversities were low compared to other heavily exploited marine fish species from the western Atlantic and eastern Asia. AMOVA depicted a lack of genetic structuring among the samples from different years, indicating the presence of a single stock of $C$. acoupa within the sample area. The possible reasons for the low levels of genetic diversity are discussed. These results demonstrate a need for the monitoring of $C$. acoupa harvesting and the preservation of the estuaries within its geographic range, considering that this large fish depends on estuarine ecosystems during part of its life cycle.
\end{abstract}

Key words: Cynoscion acoupa, acoupa weakfish, Sciaenidae, low genetic diversity, mitochondrial DNA, D-loop.

Received: September 24, 2007; Accepted: March 17, 2008.

The Sciaenidae family encompasses 70 genera and 270 species of mainly marine and estuarine fish, distributed throughout the tropical areas of the Atlantic, Indian and Pacific oceans (Trewavas, 1977; Nelson, 1994). Cynoscion, one of the most important sciaenid genera in commercial terms, is represented by eight species on the Atlantic coast of South America (Chao, 1978). One of the most prominent local sciaenids is the acoupa weakfish, Cynoscion acoupa, which is known in Brazil as the pescada amarela or yellow fish, a demersal marine species dependent on estuarine ecosystems to complete its life cycle (Barletta-Bergan et al., 2002). This species, which can reach a body length of $170 \mathrm{~cm}$, is amply distributed between Panama and Argentina (Menezes and Figueiredo, 1980; Cervigón et al., 1993), and is a very important fishery resource throughout its distribution. Fundação PROZEE (2006) reports that an average of almost 20 thousands of tons of Cynoscion

Send correspondence to Iracilda Sampaio. Laboratório de Genética e Biologia Molecular, Instituto de Estudos Costeiros, Universidade Federal do Pará, Campus de Bragança, Alameda Leandro Ribeiro sn, 68.600-000 Aldeia Bragança, PA, Brazil. E-mail: ira@ufpa.br. acoupa were landed annually in the ports of Pará and Amapá between 2000 and 2005. The most productive year was 2000 (22.8 thousand tons), whereas catches declined by more than a third between 2003 and 2005 (21.8, 17.5 and 15.0 thousand tons, respectively), although the possible determinants of this pattern remain unclear.

Despite the commercial importance of C. acoupa, the population-level genetic variability of the species is unknown. In the present study, we used DNA sequences of the mitochondrial D-loop region to characterize the genetic diversity of the C. acoupa stock from northern Brazil - the Amazon coast - using samples collected over a three year period (2003 to 2005). We hope that the parameters provided by this screening will subsidize further genetic analyses and eventual management plans for the species at a regional level.

A total of 297 adult specimens of C. acoupa were obtained from the fish market at Bragança, in the Brazilian state of Pará, in December $2003(n=23)$, April $(n=14)$ and May ( $n=400), 2004$, and in April, June, July and August of $2005(\mathrm{n}=19,50,41$, and 108, respectively). Bragança is the third largest fishing port in Pará, and receives catches pri- 
marily from the fishing grounds of the states of Amapá and Pará, which straddle the Amazon estuary.

Total DNA was isolated from muscle tissue using the conventional phenol-chloroform protocol of Sambrook et al., (1989). The following D-loop flanking primers were designed for this species: L1 5'-CCTAACTC CCAAAGCTAGGTATTC-3' and H2 5' CCGGCAGC TCTTAGCTTTAACTA - 3'. The Polymerase Chain Reaction (PCR) was carried out in a $25 \mu \mathrm{L}$ reaction containing $4 \mu \mathrm{L}$ of DNTP $(1.25 \mathrm{mM}), 2.5 \mu \mathrm{L}$ of buffer (10X), $1 \mu \mathrm{L}$ of $\mathrm{MgCl}_{2}(50 \mathrm{mM}), 0.25 \mu \mathrm{L}$ of each primer (200 ng/ $\mu \mathrm{L}), 1-2 \mu \mathrm{L}$ of total DNA (50-100 ng/ $\mu \mathrm{L})$, $0.25 \mu \mathrm{L}$ of Taq DNA Polymerase, Invitrogen, USA $(5 \mathrm{U} / \mu \mathrm{L})$, and sterile water to complete the final volume. The reactions were performed using the following schedule: initial denaturation at $94^{\circ} \mathrm{C}$ for $3 \mathrm{~min}, 35$ cycles of denaturation at $94{ }^{\circ} \mathrm{C}$ at $30 \mathrm{~s}$ - annealing at $57^{\circ} \mathrm{C}$ per $1 \mathrm{~min}$ extension at $72{ }^{\circ} \mathrm{C}$ for $2 \mathrm{~min}$, and an final extension cycle at $72{ }^{\circ} \mathrm{C}$ for $7 \mathrm{~min}$. The PCR products were purified with ExoSAP-IT (Amersham Pharmacia Biotech, USA) and submitted to the sequencing reaction using the Big Dye kit. Sequences were run in the ABI 377 (Applied Biosystems, USA), and deposited in GenBank under accession numbers EU562302-EU562598.

The D-loop sequences were aligned using CLUSTAL $\mathrm{W}$ (Thompson et al., 1994) implemented in BIOEDIT (Hall, 1999). An unrooted neighbor-joining tree was obtained in PAUP (Swofford, 2003) using the Tamura-Nei algorithm (Tamura and Nei, 1993) as suggested by Modeltest 3.7 (Posada and Crandal, 1998). Bootstrap support for internal nodes was calculated using 1,000 replicates. Haplotype $(h)$ and nucleotide $(\pi)$ diversities were estimated according to Nei (1987), using DNAsp 4.1 (Rozas et al., 2003). The variation among populations in different years was assessed using Analysis of Molecular Variance, AMOVA (Excoffier et al., 1992), implemented in ARLEQUIN 3.1 (Excoffier et al., 2005). The demographic history of C. acoupa was inferred using mismatch distribution analyses implemented in DNASP (Rozas et al., 2003). The distribution is usually multimodal in samples drawn from populations at demographic equilibrium, but it is usually unimodal in populations following a recent demographic expansion (Rogers and Harpending, 1992). Mismatch distribution analyses, under the assumption of selective neutrality, were also used to evaluate possible historical events of population growth and decline (Rogers and Harpending, 1992). Theoretical distributions under the assumption of constant population size and the sudden expansion model were compared to the observed data. The goodness-of-fit of the observed data to a simulated model of expansion was tested with the sum of squared deviations and the raggedness index (Harpending, 1994), Tajima's $D$ test (Tajima, 1989) and Fu's Fs (Fu, 1997) tests. These tests were compared to the distribution expected under the neu- tral model as generated by 1,000 simulated re-samplings. The null hypothesis of neutrality may be rejected when a population has experienced demographic expansion, bottlenecking or heterogeneous mutation rate (Tajima, 1996).

The alignment generated in the present study encompasses 831 base pairs. Variation along this D-loop fragment was very low, however, with only 42 variable sites. Of the variable sites, 28 presented two variants (informative for parsimony) and 14 were singletons. Interestingly, no variable site was observed with three or more variants, indicating that most of the D-loop variability in C. acoupa is relatively recent. Overall, 83 different haplotypes were identified (Table 1). Fifty-five (66.26\%) of these occurred just once, eleven were shared by only two individuals, whereas the remaining 14 haplotypes were found in three or more individuals. Haplotypes 1, 2, 3 and 12 were the only ones observed in all three years.

Moderate haplotype diversity $(h)$ and very low nucleotide diversity $(\pi)$ was observed in each year, and in the sample as a whole (Table 2). The AMOVA analysis indicated that there was no variation derived from differences among years and thus, no longitudinal population structuring. The phylogenetic tree for the whole population (20032005 ) depicted the 83 haplotypes in an unresolved topology with no statistical support for any of the internal branches a typical star-like topology (Figure 1). The same random distribution pattern was obtained for each of the years sampled (not shown).

Sequences of the same segment of the mitochondrial D-loop have been employed in a number of studies to investigate genetic structuring and demographic history in populations of overexploited fishes, in which the observed values of $h$ and $\pi$ were much higher than those recorded for C. acoupa in the present study. Seyoum et al.'s (2000) study of the sciaenid Sciaenops ocellatus from the Gulf of Mexico and Atlantic coast of the United States returned haplotype diversity of 0.98 and nucleotide diversity of 0.030 , and the analysis of genetic structure indicated the existence of at least two distinct populations within the study area. Higher diversity values were also recorded in three lutjanid species: Lutjanus campechanus from the Gulf of Mexico and Florida (Garber et al., 2004) with $h=0.97$, $\pi=0.018$, Lutjanus purpureus from Brazil (Gomes et al., 2008) at $h=0.99$ and $\pi=0.027$, and Lutjanus erythropterus from eastern Asia (Zhang et al., 2006), with values of $h=0.99$ and $\pi=0.030$. Colossoma macropomum (the tambaqui), one of the most heavily exploited freshwater fish in the Amazon basin (Santos et al., 2007) returned values of $h=0.99$ and $\pi=0.012$. In the present study of $C$. acoupa, estimates of haplotype diversity were ten to fifteen percent lower than those recorded in these studies, while nucleotide diversity was three to ten times lower (Table 2). In common with these studies, but to a greater degree, most 
Table 1 - Haplotype (Hap)frequencies in Cynoscion acoupa.

\begin{tabular}{|c|c|c|}
\hline Hap & Sequences & Number \\
\hline Hap1 & CCGTCCACCCCTTAGTCCATATTTGCGTACGGTAAAATACGC & 7 \\
\hline Hap2 & .А.т........ & 48 \\
\hline Hap3 & 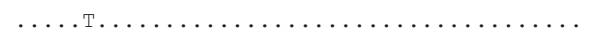 & 78 \\
\hline Hap4 & 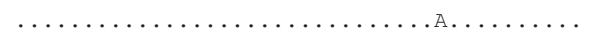 & 2 \\
\hline Hap5 & $\ldots \ldots$ т. $\ldots \ldots \ldots \ldots \ldots \ldots$ А. & 1 \\
\hline Hap6 & 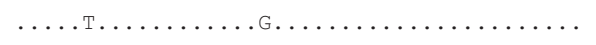 & 3 \\
\hline Hap7 & 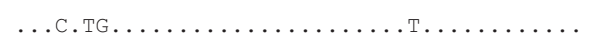 & 1 \\
\hline Hap8 & 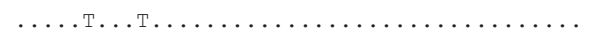 & 1 \\
\hline Hap9 & .ТА.т.т.С. & 2 \\
\hline Hap10 & …т...А. & 1 \\
\hline Hap11 & 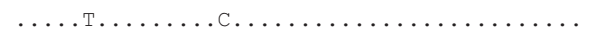 & 3 \\
\hline Hap12 & 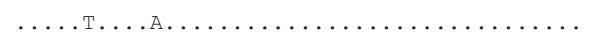 & 3 \\
\hline Hap13 & 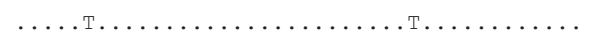 & 1 \\
\hline Hap14 & .А.т....с. & 2 \\
\hline Hap15 & .А.Т. & 2 \\
\hline Hap16 & 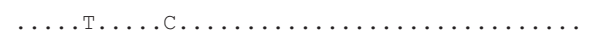 & 2 \\
\hline Hap17 & $\ldots \ldots$ т. $\ldots \ldots$ А $\ldots \ldots \ldots \ldots \ldots$ А $\ldots \ldots \ldots$ & 2 \\
\hline Hap18 & .А.т. & 2 \\
\hline Hap19 & 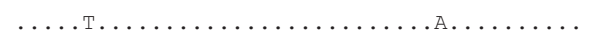 & 5 \\
\hline Hap20 & .А.т. & 1 \\
\hline Hap21 & .А.Т. & 5 \\
\hline Hap22 & 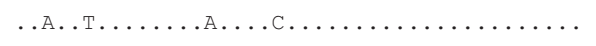 & 1 \\
\hline Hap23 & 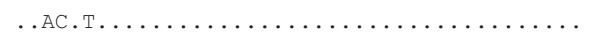 & 7 \\
\hline Hap24 & „А.Т $\ldots \ldots \ldots \ldots \ldots \ldots$ А. & 1 \\
\hline Hap25 & 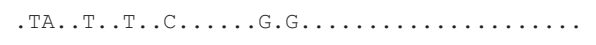 & 2 \\
\hline Hap26 & ‥т. & 2 \\
\hline Hap27 & 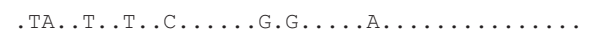 & 3 \\
\hline Hap28 & ㄷ.ТG..А. & 1 \\
\hline Hap29 & .А.т. & 1 \\
\hline Hap30 & АА.т. & 1 \\
\hline Hap31 & 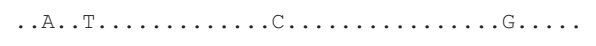 & 1 \\
\hline Hap32 & $\ldots \ldots$ т. & 3 \\
\hline Hap33 & ‥т. & 1 \\
\hline Hap34 & .А.т. & 3 \\
\hline Hap35 & ....TG............ & 5 \\
\hline Hap36 & .А.Т. & 1 \\
\hline Hap37 & 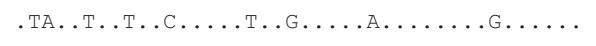 & 1 \\
\hline Hap38 & .А.т. & 1 \\
\hline Hap39 & .A. TG........... & 3 \\
\hline Hap40 & .А.Т.Т. & 3 \\
\hline Hap41 & ‥Т & 1 \\
\hline Hap42 & .ТА.т. & 1 \\
\hline
\end{tabular}

of the D-loop haplotypes observed in Brazilian C. acoupa are unique and recent (singletons).

Indices of neutral evolution (Tajima's $D$ and Fu's $F s$ ), applied to identify evidence of strong selective sweeps or balancing selection, were both negative and significant in all subpopulations as well in the population as a whole ( $\mathrm{D} \approx-1.8, \mathrm{p}=0.01$ - Table 2). Fu's Fs statistic, which was devised specifically to detect population expansion and is more sensitive to the presence of singletons (as in the pres-

\begin{tabular}{|c|c|c|}
\hline Hap & Sequences & Number \\
\hline Hap43 & .А.Т.Т. & 1 \\
\hline Hap44 & $\ldots \ldots$ т. & 1 \\
\hline Hap45 & .TA. . . . . . . . . . . . . & 1 \\
\hline Hap46 & 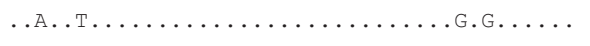 & 1 \\
\hline Hap47 & $\ldots \ldots$ G....А. & 1 \\
\hline Hap48 & $\ldots \ldots$ т......... & 2 \\
\hline Hap49 & 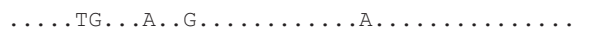 & 1 \\
\hline Hap50 & 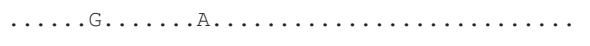 & 1 \\
\hline Hap51 & 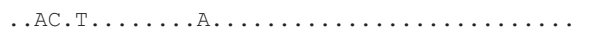 & 1 \\
\hline Hap52 & т. & 1 \\
\hline Hap53 & .А.Т...... & 1 \\
\hline Hap54 & .АС.Т $\ldots \ldots \ldots \ldots \ldots \ldots \ldots \ldots \ldots \ldots \ldots \ldots \ldots$ & 1 \\
\hline Hap55 & 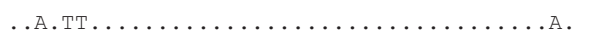 & 1 \\
\hline Hap56 & .А.Т. & 1 \\
\hline Hap57 & 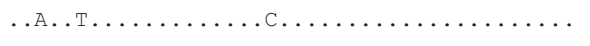 & 3 \\
\hline Hap58 & 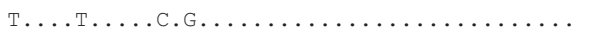 & 1 \\
\hline Hap59 & 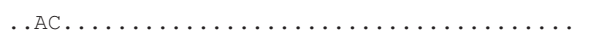 & 1 \\
\hline Hap60 & $\ldots \ldots$ т. & 1 \\
\hline Hap61 & .А.Т.Т. $\ldots \ldots \ldots \ldots \ldots \ldots \ldots \ldots \ldots \ldots \ldots$ & 1 \\
\hline Hap62 & $\ldots \ldots$ т...А. & 1 \\
\hline Hap63 & 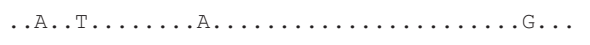 & 1 \\
\hline Hap64 & $\ldots \ldots$ т. $\ldots \ldots \ldots \ldots \ldots \ldots \ldots \ldots \ldots \ldots$ & 1 \\
\hline Hap65 & 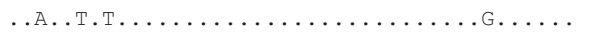 & 1 \\
\hline Hap66 & …т. & 1 \\
\hline Hap67 & 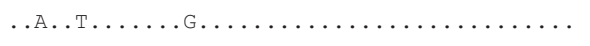 & 1 \\
\hline Hap68 & $\ldots \ldots$ TG. $\ldots$ AG $\ldots \ldots \ldots \ldots \ldots \ldots \ldots \ldots \ldots \ldots$ & 1 \\
\hline Hap69 & 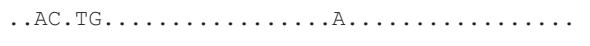 & 1 \\
\hline Hap70 & $\ldots \ldots$ т. & 1 \\
\hline Hap71 & $\ldots \ldots$ т...... & 1 \\
\hline Hap72 & 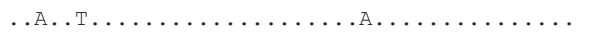 & 1 \\
\hline Hap73 & 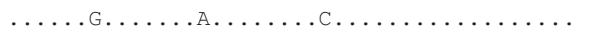 & 1 \\
\hline Hap74 & ‥т.т. & 1 \\
\hline Hap75 & АА. Т $\ldots \ldots \ldots$ А $\ldots \ldots \ldots \ldots \ldots \ldots \ldots$ & 1 \\
\hline Hap76 & $\ldots \ldots$ т. $\ldots \ldots$.А. & 2 \\
\hline Hap77 & 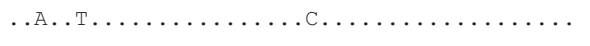 & 1 \\
\hline Hap78 & $\ldots \ldots$ т. & 1 \\
\hline Hap79 & 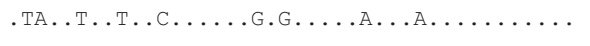 & 1 \\
\hline Hap80 & 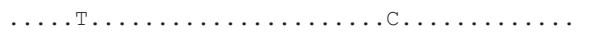 & 1 \\
\hline Hap81 & 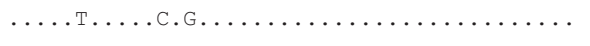 & 1 \\
\hline Hap82 & .А. & 1 \\
\hline Hap83 & $\ldots \ldots$ т.....А. & 1 \\
\hline
\end{tabular}

ent case), was also highly significant in at least two of the three subpopulations (Table $1 ; F s=-4.507$ to -26.23 ). In addition, population expansion is indicated by the mismatch distributions (Figure 2), the low raggedness index, the star-like shape of the phylogenetic tree, and the ample distribution of the most common haplotypes. The raggedness index and SSD, and expansion parameters theta and tau estimated under the expansion model are presented in Table 2. 


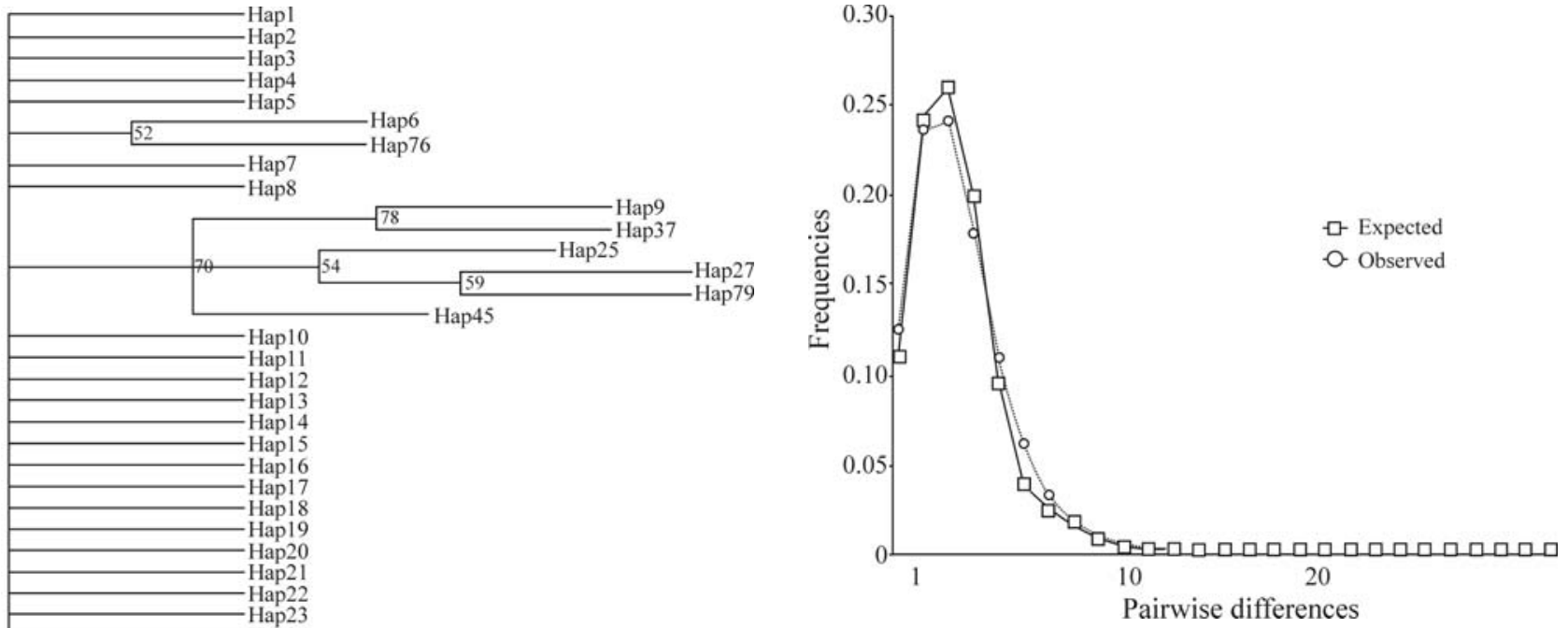

Figure 2 - Mismatch distribution for D-loop haplotypes in Cynoscion acoupa from the northern coast of Brazil. The expected frequency is based on a population growth-decline model (initial theta $=0.96$, final theta $=$ 1000 , tau $=1.427$ ), determined using the DNASP v4.20.2 program (Rozas et al., 1993).

tuary, potentially a major freshwater barrier. A single stock for this area implies that the Amazon plume is not blocking gene flow between subpopulations of $C$. acoupa from Amapá (to the north) and Pará (to the south).

However, it is not easy to identify the factor or factors responsible for the low levels of genetic diversity found in the C. acoupa stock. Overexploitation could be one factor because, despite recent improvements in technology, catches have declined progressively over the past few years. Overexploitation is identified by Dulvy et al (2003) as one of the two main causes of extinction of marine species, together with environmental degradation. These authors list more than 50 species of fishes for which overexploitation has been identified as the main cause of dramatic reductions in stocks in recent years. Nevertheless, only a few studies have related overexploitation conclusively with low levels of genetic diversity in fish populations. These include the New Zealand snapper Pagrus auratus (Hauser et al., 2002), the North Sea cod Gadus morhua (Hutchinson et al., 2003) and the dark blotched rockfish Sebastes crameri (Gomez-Uchida and Banks, 2006). While drastic reductions in stocks have been reported in a number of the species compared here with $C$. acoupa, such as the tambaqui (Colossoma macropomum), northern red snapper (Lutjanus campechanus) and red drum (Sciaenops ocellatus), no concomitant reduction in mtDNA diversity was observed.

If overexploitation is not the main cause of low levels of genetic diversity in C. acoupa, Dulvy et al. (2003) study would point to habitat degradation, although this seems unlikely in the present case, given that the Amazon coastline is still relatively sparsely populated and undeveloped. What may be more likely, considering the large number of single- 
Table 2 - Parameters of D-loop diversity, mismatch analyses and mutation neutrality tests for each year in Cynoscion acoupa from the northern coast of Brazil.

\begin{tabular}{cccccccccccc} 
Year & $\mathrm{N} 1$ & $\mathrm{H}$ & $\pi$ & $h$ & $\mathrm{SSD}$ & $\mathrm{Rg}$ & Theta 0 & Tau & $F S$ & $D$ \\
\hline 2003 & 25 & 12 & 0.00271 & 0.873 & 0.00867 & 0.04149 & 0.00176 & 2.78711 & $-4.507702^{*}$ & $-1.89049^{*}$ \\
2004 & 54 & 26 & 0.00292 & 0.906 & 0.01186 & 0.05286 & 0.0000 & 2.79883 & $-19.64201^{* *}$ & $-1.75991^{*}$ \\
2005 & 218 & 70 & 0.00291 & 0.894 & 0.01081 & 0.05274 & 0.0000 & 3.03516 & $-26.23168^{* *}$ & $-1.75926^{*}$ \\
Total & 297 & 83 & 0.00288 & 0.892 & 0.00091 & 0.03594 & 0.38496 & 1.83789 & $-16.62155^{*}$ & $-1.82357^{*}$ \\
\hline
\end{tabular}

${ }^{1} \mathrm{~N}=$ number of specimens; $\mathrm{H}=$ number of haplotypes; $\pi$ = nucleotide diversity; $h=$ haplotype diversity; $\mathrm{SSD}=$ sum of squared deviation; Rg = Raggedness index; Theta and Tau $=$ expansion parameters estimated under the expansion model; Fs $=$ Fu's $F s ; D=$ Tagima's $D ; *=\mathrm{p}<0.05 ; * *=\mathrm{p}<0.01$.

tons identified in the present study, the star-like phylogenetic tree, and the evidence of rapid population expansion, is that C. acoupa has passed through a major bottleneck, which has erased much of its original variability, followed by a recent process of expansion. A similar explanation has been offered for the population mtDNA variability pattern observed in Lutjanus campechanus (Garber et al., 2004) and Lutjanus erythropterus (Zhang et al., 2006).

In conclusion, the present analysis has revealed that the $C$. acoupa population sampled from northern Brazil represents a single stock that occupies at least $1260 \mathrm{~km}$ of coastline $($ Amapá $=698 \mathrm{~km}$, Pará $=562 \mathrm{~km})$. This area encompasses a number of estuaries other than the Amazon, which may be important for the reproductive cycle of the species, and demand attention with regard to its conservation. In addition, the low levels of genetic variability observed here may compromise the evolutionary plasticity of this $C$. acoupa population. These findings indicate an urgent need for the careful monitoring of the harvesting of $C$. acoupa in northern Brazil.

\section{Acknowledgments}

This study was funded by grants from CNPqPADCT/MCT 620052/01-5 (Millenium Project), CNPq/ DLR 491179/2005-7 (International Cooperation Brazil/ Germany), CNPq 308477/2006-5 (Bolsas no País/ Produtividade em Pesquisa - PQ - 2006) and CNPq 477542/2006-9 (Edital Universal).

\section{References}

Barletta-Bergan A, Barletta M and Saint-Paul U (2002) Structure and seasonal dynamics of larval fish in the Caete River Estuary in North Brazil. Est Coastal Shelf Sci 54:193-206.

Cervigón F, Ciprini R, Fischer W, Garibaldi L, Hendrickx G and Rodriguez B (1993) FAO Species Identification Sheets for Fishery Purposes. Field Guide to the Commercial Marine and Brackish-Water Resources of the Northern Coast of South America. FAO, Rome, 513 pp.

Chao NL (1978) A Basis for Classifying Western Atlantic Sciaenidae (Teleostei, Perciformes). National Marine Fisheries Service, Washington D.C. 64 pp.

Dulvy NK, Sadovy Y and Reynolds JD (2003) Extinction vulnerability in marine populations. Fish Fisheries 4:25-64.

Excoffier L, Smouse PE and Quattro JM (1992) Analysis of molecular variance inferred from metric distances among DNA haplotypes: Application to human mitochondrial DNA restriction data. Genetics 131:479-491.

Excoffier L, Laval G and Schneider (2005) Arlequin ver. 3.0: An integrated software package for population genetics data analysis. Evol Bioinf Online 1:47-50.

Fu YX (1997) Statistical tests of neutrality of mutations against population growth, hitchhiking and background selection. Genetics 147:915-925.

Fundação PROZEE (2006) Relatório Final do Projeto de Monitoramento da Atividade Pesqueira no Litoral do Brasil Projeto Estatpesca. SEAP, Brasilia, 328 pp.

Garber AF, Tringali MD and Stuck KC (2004) Population structure and variation in red snapper (Lutjanus campechanus) from the Gulf of Mexico and Atlantic Coast of Florida as determined from mitochondrial DNA control region sequence. Mar Biotechnol 6:175-185.

Gomes G, Schneider H, Vallinoto M, Santos S, Orti G and Sampaio I (2008) Can Lutjanus purpureus (South red snapper) be "legally" considered a red snapper (Lutjanus campechanus)? Genet Mol Biol 31:372-376.

Gomez-Uchida D and Banks MA (2006) Estimation of effective population size for the long-lived darkblotched rockfish Sebastes crameri. J Hered 97:603-606.

Hall TA (1999) BioEdit: A user-friendly biological sequence alignment editor and analysis program for Windows 95/98/NT. Nucleic Acids Symp Ser 41:95-98.

Harpending HC (1994) Signature of ancient population growth in a low-resolution mitochondrial DNA mismatch distribution. Hum Biol 66:591-600.

Hauser L, Adcock GJ, Smith PJ, Ramirez JHB and Carvalho GR (2002) Loss of microsatellite diversity and low effective population size in an overexploited population of New Zealand snapper (Pagrus auratus). Proc Natl Acad Sci USA 99:11742-11747.

Hutchinson WF, van Oosterhaut C, Rogers SI and Carvalho GR (2003) Temporal analysis of archived samples indicates marked genetic changes in declining North Sea cod (Gadus morhua). Proc R Soc Lond Ser B Biol Sci 270:2125-2132.

Menezes NA and Figueiredo JL (1980) Manual de Peixes Marinhos do Sudeste do Brasil. Volume IV. Teleostei. Museu de Zoologia da Universidade de São Paulo, São Paulo, 110 pp.

Nei M (1987) Molecular Evolutionary Genetics. Columbia Univ. Press, New York, 512 pp.

Nelson JS (1994) Fishes of the World. 3rd ed. John Wiley and Sons Inc., New York, 600 pp.

Posada D and Crandal KA (1998) MODELTEST: Testing the model of DNA substitution. Bioinformatics 14:817-818. 
Rogers AR and Harpending HC (1992) Population growth makes waves in the distribution of paiwise differences. Mol Biol Evol 9:552-559.

Rozas J, Sánchez-DelBarrio JC, Messeguer X and Rozas R (2003) DnaSP. DNA polymorphism analysis by the coalescent and other methods. Bioinformatics 19:2496-2497.

Sambrook J, Fritsch EF and Maniatis T (1989) Molecular Cloning: A Laboratory Manual. 2nd ed. Cold Spring Harbor Laboratory Press, New York, 1659 pp.

Santos MCF, Ruffino ML and Farias IP (2007) High levels of genetic variability and panmixia of the tambaqui Colossoma macropomum (Cuvier, 1816) in the main channel of the Amazon River J Fish Biol 71:33-44.

Seyoum S, Tringali MD, Bert TM, McElroy D and Stokes R (2000) An analysis of genetic population structure in red drum, Sciaenops ocellatus, based on mt DNA control region sequences. Fish Bull 98:127-138.

Swofford DL (2003) PAUP*, Phylogenetic Analysis Using Parsimony (*and Other Methods). Version 4. Sinauer Associates, Inc. Publisher, Sunderland.

Tajima F (1989) Statistical method for testing the neutral mutation hypothesis by DNA polymorphism. Genetics 123:585-595.
Tajima F (1996) The amount of DNA polymorphism maintained in a finite population when the neutral mutation rate varies among sites. Genetics 143:1457-1465.

Tamura F and Nei M (1993) Estimation of the number of nucleotide substitutions in the control region of mitochondrial DNA in humans and chimpanzees. Mol Biol Evol 10:512526.

Thompson JD, Higgins DG and Gibson TJ (1994) Clustal W: Improving the sensitivity of progressive multiple sequence alignment through sequence weighting, position-specific gap penalties and weight matrix choice. Nucleic Acid Res 22:4673-4680.

Trewavas E (1977) The sciaenidae fishes (croakers or drums) of the Indo-West-Pacific. Trans Zool Soc Lond 33:253-541.

Zhang J, Cai Z and Huang L (2006) Population genetic structure of crimson snapper Lutjanus erythropterus in East Asia, revealed by analysis of the mitochondrial control region. J Mar Sci 63:693-704.

\section{Associate Editor: Fausto Foresti}

License information: This is an open-access article distributed under the terms of the Creative Commons Attribution License, which permits unrestricted use, distribution, and reproduction in any medium, provided the original work is properly cited. 